\title{
Unexplained Foetal Deaths and Synalbumin Insulin Antagonism
}

\author{
J.J. Consoy
}

Department of Medicine, The Queen's University of Belfast, Northern Ireland

Received: November 4, 1968

\begin{abstract}
Summary. Diabetic levels of the synalbumin insulin antagonist were found in $30 \%$ of a group of 50 women who had had unexplained intrauterine foetal deaths. Four per cent of the control group had similar levels of antagonism. Previous reports of an increased foetal mortality in potentially diabetic women were confirmed.

Morts foetales inexpliquées et antagonisme synalbumineinsuline

Résumé. Des valeurs diabétiques de la synalbumine, antagoniste de l'insuline ont été trouvées chez $30 \%$ d'un groupe de 50 femmes chez lesquelles les morts foetales intra-utérines étaient inexplicables. $4 \%$ du groupe témoin avaient des valeurs semblables de l'antagoniste de l'insuline. Nos résultats confirment les observations
\end{abstract}

précédentes indiquant une mortalité foetale accrue chez les femmes potentiellement diabétiques.

Ungeläärter intrauteriner Fruchttod und SynalbuminInsulin-Antagonismus

Zusammenfassung. Bei 30\% einer Gruppe von 50 Frauen, bei denen ein intrauteriner Fruchttod aus ungeklärter Ursache aufgetreten war, fanden sich gleiche Mengen des Synalbumin-Insulin-Antagonisten wio bei Diabetikern. Von der Kontrollgruppe hatten nur 4\% die gleiche Menge des Insulinantagonisten. Unsere Resultate stimmen mit den Literaturangaben über eine vermehrte embryonale Sterblichkeit bei potentiell diabetischen Müttern überein.

Key-words: Foetal death, Synalbumin insulin antagonism, Potential diabetes.

\section{Introduction}

The high perinatal mortality of infants of diabetic women is well known and even with the best management rarely falls below 15\% (HARLEX and MoNTGOMERY, 1965; OAKLEY, 1965). Several factors are responsible for the poor foetal prognosis. They include maternal acidosis (Crenshaw, Parker and Carter, 1962), respiratory distress (HsIA, 1959; MILLER, 1965), toxaemia of pregnancy (KYLE, 1963), diabetic vascular disease (PEDERSEN, 1965), and congenital abnormalities (Pedersen, Tygstrup and Pedersen, 1964; Driscoll, 1965). However, unexplained foetal death frequently occurs even in the mildest and best controlled diabetics. This suggests that the harmful effect of maternal diabetes is not necessarily associated with abnormalities of carbohydrate metabolism; and this view is supported by a number of retrospective investigations, which have shown a high perinatal mortality in prediabetic women long before the recognition of diabetes (Muller, Hurwitz and Kuder, 1944; Paton, 1948; GILbert and Dunlop, 1949; JaCkson and Woolf, 1956; HaGBard, 1958). Prediabetes refers to that period in the life of a diabetic before the diagnosis of diabetes, and since it is a retrospective classification inevitably includes some patients with asymptomatic but unrecognised diabetes. Indeed some investigators who failed to show an increased foetal mortality in the prediabetic period, concluded that asymptomatic diabetes had been inadvertently included as prediabetics in the earlier work (Bononow and MoELIN, 1965). However, high mortality rates were found up to 30 years before the diagnosis of diabetes in some instances (PAtron, 1948; GLLBert and DunLop, 1949), and it is difficult to accept that such patients were overt but undiagnosed diabetios at the time of the foetal death.

Thus, although the evidence is suggestive of a relationship between prediabetes and foetal wastage, it is not conclusive largely because of the retrospective nature of earlier investigations, which lacked any means of identifying a potential diabetic at the time the foetal death occurred.

Synalbumin is an albumin-bound antagonist of insulin which is present in higher concentrations in the blood of diabetics and potential diabetics than in normal subjects (Vatrancer-OWEN, Dennes and CAMPBHLL, 1958), and so may be used to recognise potential diabetics without reference to carbohydrate tolerance.

The Synalbumin levels of a group of women with unexplained intrauterine foetal death have been measured in an effort to clarify the relationship of potential diabetes to foetal mortality.

\section{Material and Methods}

One hundred females, whose ages ranged from 1747 years, were investigated. One half (group A) had a history of unexplained intrauterine foetal death during the last trimester of pregnancy, and the remainder (group B) were selected from the records of the Royal Maternity Hospital in order of admission, excluding those patients with a history of stillbirth or any recognised cause of stillbirth such as diabetes, accidental haemorrhage, lethal congenital malformations, severe pre-eclampsia or hydramnios, which had precluded admission to group $\mathrm{A}$. In most cases height and weight were measured at the first antenatal visit, usually about three months after the last menstrual period. When a 
patient presented at a later date, her weight was adjusted to the expected weight at three months by reference to the tables of STANDER and PASTORE (1940).

$50 \mathrm{~g}$ oral glucose tolerance tests were carried out on the subjects in group A after they had taken a carbohydrate-rich diet for three days. Venous blood sugar values were estimated by the Hoffman ferricyanide reduction method on a Technicon Autoanalyser.

In two-thirds of cases the test was done in the third trimester or the first week postpartum, and no blood glucose values exceeding two or more of the following levels were found - fasting and $2 \mathrm{~h}, 110 \mathrm{mg} ; 1 \mathrm{~h}, 160 \mathrm{mg}$.

About one-third were tested at least three months postpartum and no values exceeding two or more of the following were found-fasting and $2 \mathrm{~h}, 110 \mathrm{mg} ; 1 \mathrm{~h}$, $150 \mathrm{mg}$.

Preparation of Albumin. Venous blood samples were collected in heparinised tubes after an overnight fast. In all cases at least three months had elapsed since the last pregnancy, to avoid any possible effects of the puerperium on carbohydrate metabolism. Albumin was extracted by the method of DeBro, TARVER and KorNer (1957) as modified by VALLANCE-OWEN et al. (1958).

Assay Procedure. Insulin antagonism was measured by the rat diaphragm technique according to the method of VALLANCE-OWEN and HURLOCK (1954). In any one experiment, three albumin preparations were assayed in triplicate at $1.25 \%$ concentration with $1000 \mu \mathrm{U}$ per $\mathrm{ml}$ of insulin, and their effect on the glucose uptake of the rat hemidiaphragm expressed as a percentage of the glucose uptake produced by $1000 \mu \mathrm{U}$ per $\mathrm{ml}$ of insulin alone.

\section{Results}

The effect on glucose uptake of individual albumin samples ranged from 30 to $171 \%$ of the effect of insulin

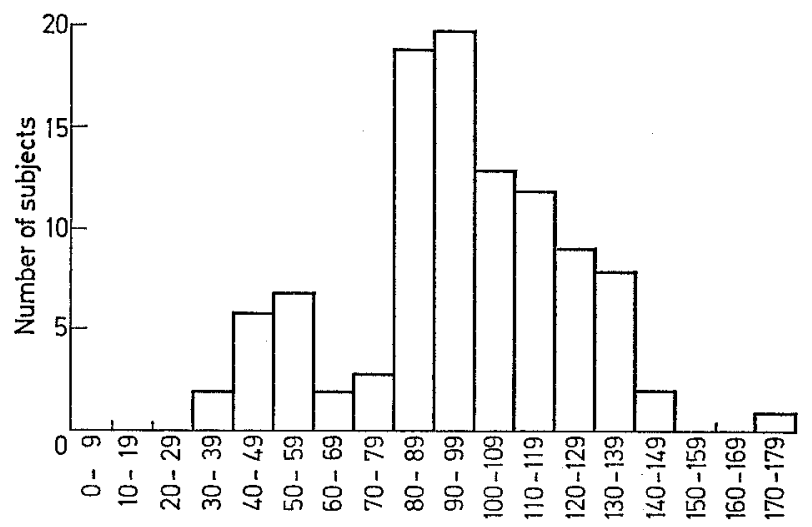

Fig. 1. Glucose uptake above basal of individual albumin samples +1000 microunits Insulin/ml, as a percentage of the insulin uptake alone

alone (Fig. 1). All the Synalbumin-positive albumins had more than $40 \%$ insulin antagonism, except two which had $\mathbf{3 3} \%$ and $\mathbf{3 7 \%}$ antagonism respectively.
The effect sof individual Synalbumin-negative samples ranged from 74 to $171 \%$ of the insulin effect. The mean effect was $105 \% \pm$ standard deviation $19.4 \%$. Three values were greater than $140 \%$.

It can be seen that the non-antagonistic albumins fall into two groups - those which have no effect on the insulin stimulated glucose uptake and those which increase it. Further unpublished work shows that albumin prepared from some Synalbumin-negative subjects has by itself marked insulin-like activity and this may explain the latter results.

Table 1. Comparison of numbers of Synalbumin-positive and negative patients in groups $A$ and $B$

\begin{tabular}{lccc}
\hline & Group A & Group B & Total \\
\hline Synalbumin-positive & 15 & 2 & 17 \\
Synalbumin-negative & $\mathbf{3 5}$ & 48 & 83 \\
\hline Total & 50 & 50 & 100 \\
\hline \multicolumn{4}{c}{$\begin{array}{l}\chi^{2}=10.206 \\
n=1 \\
0.01>P>0.001\end{array}$} \\
\end{tabular}

Table 2. Assay results for groups $A$ and $B$

\begin{tabular}{|c|c|c|}
\hline \multirow{2}{*}{$\begin{array}{l}\text { Source and status of } \\
\text { albumin } \\
\text { (No.) }\end{array}$} & \multicolumn{2}{|c|}{$\begin{array}{l}\text { Mean glucose uptake above } \\
\text { basal level } \pm \text { standard } \\
\text { error of mean }\end{array}$} \\
\hline & $\begin{array}{l}\text { Buffer }+ \\
1000 \mu \mathrm{U} / \mathrm{ml} \\
\text { insulin }\end{array}$ & $\begin{array}{l}1.25 \% \\
\text { albumin }+ \\
1000 \mu \mathrm{U} / \mathrm{ml} \\
\text { insulin }\end{array}$ \\
\hline \multicolumn{3}{|l|}{ Group $A$} \\
\hline Antagonistic (15) & $14.6 \pm 0.93$ & $7.2 \pm 0.61$ \\
\hline Non-ant & $12.9 \pm 0.35$ & $12.5 \pm 0.3$ \\
\hline \multicolumn{3}{|l|}{ Group $B$} \\
\hline Antagonisti & 16.0 & 9.6 \\
\hline Non-antagonistic (48) & $12.9 \pm 0.52$ & $13.7 \pm 4.2$ \\
\hline
\end{tabular}

Because of the small number of antagonistic albumins in group $B$ the standard error of the mean is not valid.

Table 1 compares the number of Synalbumin-positive and Synalbumin-negative patients in groups $A$ and B. In group A 15 women were positive and in group $B$ two women were positive, a difference which is statistically highly significant $(0.01>P>0.001)$.

Table 2 shows the mean \pm the standard error of the mean, of the effect of Synalbumin-positive and Synalbumin-negative albumins on the insulin-stimulated glucose uptake in groups A and B. The figures in brackets refer to the number of subjects tested.

The weights of the patients in group A did not differ significantly from those in group $B\left(\chi^{2}=7.7748\right.$; $\mathrm{n}=3 ; 0.20>P>0.10$ ), though there was a tendency towards heavier weights than expected in group A. Synalbumin-positive and negative women did not differ significantly in weight. The Synalbumin-negative women in group A were not significantly heavier than those in group $B(0.10>P>0.05)$. 
The effects of individual synalbumin negative samples plus $1000 \mu \mathrm{U}$ of insulin ranged from 74 to $171 \%$ of the effect of insulin alone. The mean was $105 \% \pm$ standard deviation $19.4 \%$. Three values were greater than $140 \%$.

\section{Discussion}

Increasing attention has been paid recently to the diagnosis, manifestations and management of potential diabetes but full investigation of the problem has been hampered by the lack of a suitable means of identifying the individual potential diabetic.

Recognition of these patients is particularly important during pregnancy because of the high perinatal infant mortality rate of women who later develop diabetes (MIILER, 1945; GILBERT and DUNLOP, 1949). However, not all workers are agreed that maternal potential diabetes constitutes a foetal hazard (PIRART, 1955; BoRonow and McEurn, 1965; Graves, NEFF and MARK, 1967) and it has been suggested that those series which showed such a relationship, were biased by the inclusion of latent or chemical diabetes.

Assay of albumin samples for insulin antagonism allows a distinction to be drawn between normal subjects and potential diabetics (VALLANCE-OWEN, 1966), and in the present investigation almost one-third of the women who had had unexplained intrauterine foetal deaths were found to be synalbumin positive as opposed to $4 \%$ of the control subjects. The pathogenesis of these deaths remains obscure. They are not due to hyperglycaemia or to any obvious complications of diabetic pregnancy such as lethal malformations or toxaemia and it may be that synalbumin is damaging to the foetal metabolism. The characteristic appearance of the infant of a diabetic mother may be explained by excess synalbumin passing from the maternal to the foetal circulation necssitating increased secretion of insulin by the pancreas to overcome the insulin antagonism.

An increase in foetal insulin antagonism and human placental lactogen would favour the liberation of fatty acids and ketone bodies with resultant keto-acidosis and if this was sufficiently grave would be just as damaging to the foetus as a similar degree of maternal acidosis. Such a metabolic death would explain the frequent absence of grave pathological changes in these foetuses.

One of the most puzzling features of the potential diabetics in this series and of diabeties in general is the occurrence of entirely normal pregnancies before and after a perinatal death. Synalbumin is inherited as an autosomal dominant (VALLANCE-OWEN, 1966) and it may be that only those foetuses whose environment is rendered doubly hostile both by inheritance of the antagonist and by its passage across the placenta are at risk. Thus, the increasing stillbirth rate after the thirty-second week of pregnancy could be explained by increasing maternal and foetal production of synalbu- min. Alternatively the level of antagonism may vary from pregnancy to pregnancy.

In the light of evidence showing that the perinatal mortality of obese women is increased (SHELDON, 1949) it is interesting to note that the synalbumin negative women in group $A$ were no heavier than those in group $B$. The similar weights of the synalbumin positive and negative subjects was unexpected since the antagonist allows unimpeded action of insulin on fat tissue and one might expect herefore that the former group should be heavier. It may be that differences in weight will become obvious when enough time has elapsed to allow increased deposition of fat.

There are many fewer synalbumin positives patients in the present control group compared with those previously reported (VALLAIOE-OWEN, 1963; WILSON and VALLANCE-OWEN, 1966) in which incidences of $21 \%$ and $25 \%$ respectively were found. The explanation of these differences probably lies in the composition of the groups. The present controls were selected from the Maternity Hospital records in order of admission, excluding those women who had had complications of pregnancy such as accidental haemorrhage, overt diabetes or conditions which engender a suspicion of potential diabetes like progressive obesity of pregnancy, repeated unexplained stillbirths, hydramnios or pre-eclampsia. Such criteria were not applied to the control groups previously mentioned and this may explain the different incidence of synalbumin positive subjects in them. It is felt, however, that this is not the complete explanation and other undetermined factors are probably involved.

Acknowledgements. I should like to thank Professor VALLATOE-OwEN for his helpful advice during this work; and the Royal Victoria Hospital for a Research Fellowship; the consultant obstetricians of the Royal Maternity, Belfast City and Ulster Hospitals, Belfast for allowing me to study their patients; Miss May MACAULEY for valuable technical help.

\section{References}

Boronow, R.C., and T.W. MoEnIN: Diabetes in pregnancy. Amer. J. Obstet. Gynec. 91, 1022-1028 (1965). CARDELL, B.S.: 'The infants of diabetic mothers. J. Obstet. Gynaec. Brit. Emp. 60, 834-853 (1953).

Crenshaw, C., R.T. Parker, and B. Carter Diabetes mellitus and pregnancy. Obstet. and Gynec. 20, 334 341 (1962).

Debro, J.R., E. Tarver, and A. Korner: The determination of serum albumin and globulin by a now method. J. Lab. clin. Med. 50, 728-732 (1957).

DRIscold, S.G.: The pathology of pregnancy complicated by diabetes mellitus. Med. Clin. N. Amer. 49, 1053$1067(1965)$.

Fer, B.A., and W.B. WeIt, Jr.: Body composition of infants of diabetic mothers by direct analysis. Amer. J. Dis. Child. 100, 718-719 (1960).

GILBERT, J.A.L., and D.M. DUNLOP: Diabetic maternal mortality and foetal loss rate. Brit. med. J., 1949 I, $48-51$.

Graves, W.K., R. NEFF, and P. MarK: Altered glucose metabolism in pregnancy. Amer. J. Obstet. Gynec. 98, $602-606(1967)$. 
Hagbard, L.: The prediabetic period from an obstetric point of view. Acta obstet. gynec. scand. 37 (4), 497$518(1958)$.

HaRLeY, J.M.G., and D.A.D. Montgomery: Management of pregnancy complicated by diabetes. Brit. med. J., 1965 I, 14-18.

HuLTQuist, G., L. Olding, and Y.A.A. LaRson: Some histopathologic quantitative observations on the pancreatic islets of infants of diabetic mothers. Abstracts 5th Congress Internat. Diabetes Fed. Excerpta med. Internat. Congr. Ser. No. 74, Abstract No. 129 (1964).

JACKSON, W.P.U., and N. WooLF: Natural history of prediabetes. New Engl. J. Med. 255, 1183-1185 (1956).

KYL, G.C.: Diabetes and pregnancy. Ann. Int. Med. 59, Suppl. 3 (1963).

MrLimR, H.C.: Effect of prediabetic state on survival and birthweight of newborn infants. New Engl. J. Med. 233, $376-378$ (1945).

- D. HuRwixz, and K. Kuder : Fetal and neonatal mortality in pregnancies complicated by diabetes mellitus. J.A.M.A. 124, $271-275$ (1944).

MrrueR, M.: Diabetic pregnancy and fetal survival in a large metropolitan area. In: On the Nature and Treatment of Diabetes. Eds. B.S. Letrex and G. A. WRENsHAT, p. 714. Amsterdam: Excerpta medica Found. 1965.

OAKLEY, W.: The treatment of pregnancy in diabetes mellitus. In: On the Nature and Treatment of Diabetes. Eds. B.S. Lerbit and G.A. Wrenshati. Amsterdam: Excerpta medica Found 1965.

OkUdama, Y., K. Hirota, S. Coheen, and L. Stratuss: Ultrastructure of the human placenta in maternal diabetes mellitus. Lab. Invest. 15, 910-926 (1966).

Paton, D.M. : Pregnancy in the prediabetic patient. Amer. J. Obstet. Gynec. 56, 558-560 (1948).
Pedersen, J.: Foetal mortality in pregnancy of diabetics. Acta endocr. 50, 95-103 (1965).

Pefdersen, L.M., I. Tygstrut, and J. Pedersen: Congenital malformations in newborn infants of diabetic women. Lancet 1964 I, $1124-1126$.

Pirart, J.: The so-called prediabetic syndrome of pregnancy. Acta endocr. 20, 192-208 (1955).

SHeLdoN, J.H.: Maternal Obesity. Lancet 1949 I, $869-873$.

Sotto, L.S.J., D.P. Heintrack, and A.W. Stegner: Unsuspected prediabetic state and pregnancy. Amer. J. Obstet. Gynec. 76, 425-431 (1958).

Stander, H.J., and J.B. PAstori: Weight changes during pregnancy and puerperium. Amer. J. Obstet. Gynec. 39, 928-937 (1940).

VALIANCE-OWEN, J.: The inheritance of essential diabetes mellitus from studies of the synalbumin insulin antagonist. Diabetologia 2, 248-252 (1966).

-, and B. HurLock: Estimation of plasma insulin. Lancet 1954 I, 68-70.

- E. Drannes, and P.N. CAMPBell: Insulin antagonism in plasma of diabetic patients and normal subjects. Lancet 1958 II, 336-338.

-, and W.L. AserTox: Cardiac infaretion and insulin antagonism. Lancet 1963, 1, 1226-1228.

WIISON, J.S.P., and J. VALLANCE-OWEN: Congenital malformations and insulin antagonism. Lancet $\mathbf{1 9 6 6} \mathbf{I I}$, $940-941$.

J.J. CoNnON M.D., M.R.C.P.

The Department of Medicine

The Queen's University of

Belfast, Northern Ireland. 